\title{
Study of Performance Characteristics of Single Cylinder Diesel Engine Using Water Emulsified Diesel as Fuel
}

\author{
Deepak Dinesh Prasad \\ LDRP College of Engineering, Gandhinagar, India
}

\begin{abstract}
In this research paper the effect of water in diesel emulsion on performance characteristics of diesel engine has been studied. Various combination of water in diesel emulsion that is $5 \%$ water denoted as W5, 10\% water denoted as W10, $20 \%$ water denoted as W20 and 30\% water denoted as W30 are used in the experiment carried out to find the emulsion which gives best performance characteristics for diesel engine. Best performance characteristics of diesel engine here stands for high brake thermal efficiency, high torque, higher brake power and low brake specific fuel consumption. Thus test was carried out first using pure diesel and then W5, W10, W20 and W30 respectively and the readings were noted down in observation tables and graphs were drawn and conclusion was arrived by carefully analysing the graphs. By using water in diesel emulsion the peak temperature in the combustion chamber is lowered which gives many advantages like low emissions from the engine.
\end{abstract}

Keywords: performance characteristics, load, torque, brake power, brake thermal efficiency, brake specific fuel consumption, emulsion, peak temperature

\section{Introduction}

In order to attain high brake thermal efficiency combined with low brake specific fuel consumption we use water in diesel emulsion in place of pure diesel oil. When water in diesel emulsion is sprayed in the combustion chamber the water droplets absorb the latent heat of vaporisation from the combustion gases and get converted into steam and thus peak pressure increases. In other words the heat which is lost from the cylinder liner jacket to cooling water and the heat loss in the exhaust is utilised in the formation of steam in the combustion chamber. Also as a result of micro explosion phenomenon of water droplets there is good mixing of fuel and air which results in efficient combustion. Thus due to high peak pressure the torque increases which results in increase in brake power combined with high brake thermal efficiency and low brake specific fuel consumption.

\section{Material and Methods}

The engine specification used for the experiment is mentioned below along with the procedure for carrying out the experiment.

\subsection{Engine Specifications}

Kirloskar Engine Type AVI

Power3.7 KW@1500 RPM

Mechanical dynamometer with radius of arm 0.14 meter.

Starting by hand crank manually using decompression lever.

\subsection{Procedure for carrying out experiment}

1) The filters of the engine is to be replaced and the injectors is to be cleaned and calibrated according to the desired pressure.

2) The fuel tank is to be filled with pure diesel and the engine is to be run.
3) The engine should run at various loads of the dynamometer $-1,2,3,4,5 \mathrm{~kg}$ and respective readings were taken for fuel consumption/minute.

4) After all the readings are taken, the leftover diesel should be drained out of the tank and emulsion is to be poured.

5) Same steps were repeated for emulsion and the readings were noted down for the emulsion.

6) After taking all the observations graphs were plotted to compare the performance characteristics of the engine in case of diesel and emulsions W5, W10, W20 and W30.

\section{Observation Tables}

3.1 Table for Performance Characteristics of Pure Diesel Oil

\begin{tabular}{|c|c|c|c|c|c|c|}
\hline $\begin{array}{c}\text { Sr } \\
\text { No. }\end{array}$ & RPM & $\begin{array}{c}\text { Load } \\
\text { in } \\
\text { KG }\end{array}$ & $\begin{array}{c}\mathrm{M}_{\mathrm{f}} \text { in } \\
\text { KG/HR }\end{array}$ & $\begin{array}{c}\text { Brake } \\
\text { Power } \\
\text { in KW }\end{array}$ & $\begin{array}{c}\text { Brake Specific } \\
\text { Fuel } \\
\text { Consumption } \\
\text { in G/(KWHR) }\end{array}$ & $\begin{array}{c}\text { Brake } \\
\text { Thermal } \\
\text { Efficiency } \\
\text { in \% }\end{array}$ \\
\hline 1 & 1490 & 1 & 0.1835 & 0.214 & 0.857 & 10 \\
\hline 2 & 1470 & 2 & 0.226 & 0.422 & 0.535 & 16 \\
\hline 3 & 1460 & 3 & 0.245 & 0.629 & 0.389 & 22 \\
\hline 4 & 1450 & 4 & 0.285 & 0.833 & 0.342 & 25 \\
\hline 5 & 1430 & 5 & 0.303 & 1.027 & 0.295 & 29 \\
\hline
\end{tabular}

\subsection{Table for Emulsion W5 Performance Characteristics}

\begin{tabular}{|c|c|c|c|c|c|c|}
\hline $\begin{array}{c}\text { Sr } \\
\text { No. }\end{array}$ & RPM & $\begin{array}{c}\text { Load } \\
\text { in } \\
\text { KG }\end{array}$ & $\begin{array}{c}\mathrm{M}_{\mathrm{f}} \text { in } \\
\mathrm{KG} / \mathrm{HR}\end{array}$ & $\begin{array}{c}\text { Brake } \\
\text { Power } \\
\text { in KW }\end{array}$ & $\begin{array}{c}\text { Brake Specific } \\
\text { Fuel } \\
\text { Consumption } \\
\text { in G/(KWHR) }\end{array}$ & $\begin{array}{c}\text { Brake } \\
\text { Thermal } \\
\text { Efficiency } \\
\text { in \% }\end{array}$ \\
\hline 1 & 1490 & 1 & 0.19 & 0.214 & 0.88 & 10.19 \\
\hline 2 & 1470 & 2 & 0.24 & 0.422 & 0.56 & 15.9 \\
\hline 3 & 1460 & 3 & 0.28 & 0.629 & 0.44 & 20.3 \\
\hline 4 & 1450 & 4 & 0.31 & 0.833 & 0.37 & 24.3 \\
\hline 5 & 1430 & 5 & 0.33 & 1.027 & 0.32 & 28.15 \\
\hline
\end{tabular}




\section{International Journal of Science and Research (IJSR) \\ ISSN (Online): 2319-7064}

Index Copernicus Value (2013): 6.14 | Impact Factor (2015): 6.391

3.3 Table for Emulsion W10 Performance Characteristics

\begin{tabular}{|c|c|c|c|c|c|c|}
\hline $\begin{array}{c}\text { Sr } \\
\text { No. }\end{array}$ & RPM & $\begin{array}{c}\text { Load } \\
\text { in } \\
\text { KG }\end{array}$ & $\begin{array}{c}\mathrm{M}_{\mathrm{f}} \text { in } \\
\text { KG/HR }\end{array}$ & $\begin{array}{c}\text { Brake } \\
\text { Power } \\
\text { in KW }\end{array}$ & $\begin{array}{c}\text { Brake Specific } \\
\text { Fuel } \\
\text { Consumption } \\
\text { in G/(KWHR) }\end{array}$ & $\begin{array}{c}\text { Brake } \\
\text { Thermal } \\
\text { Efficiency } \\
\text { in \% }\end{array}$ \\
\hline 1 & 1490 & 1 & 0.26 & 0.214 & 1.21 & 7.8 \\
\hline 2 & 1470 & 2 & 0.39 & 0.422 & 0.92 & 10.3 \\
\hline 3 & 1460 & 3 & 0.48 & 0.629 & 0.76 & 12.5 \\
\hline 4 & 1450 & 4 & 0.60 & 0.833 & 0.72 & 13.3 \\
\hline 5 & 1430 & 5 & 0.75 & 1.027 & 0.73 & 13.11 \\
\hline
\end{tabular}

3.4 Table for Emulsion W20 Performance Characteristics

\begin{tabular}{|c|c|c|c|c|c|c|}
\hline $\begin{array}{c}\text { SR } \\
\text { NO. }\end{array}$ & RPM & $\begin{array}{c}\text { Load } \\
\text { in KG }\end{array}$ & $\begin{array}{c}\mathrm{M}_{\mathrm{f}} \text { IN } \\
\text { KG/HR }\end{array}$ & $\begin{array}{c}\text { Brake } \\
\text { Power } \\
\text { in KW }\end{array}$ & $\begin{array}{c}\text { Brake Specific } \\
\text { Fuel } \\
\text { Consumption } \\
\text { in G/(KWHR) }\end{array}$ & $\begin{array}{c}\text { Brake } \\
\text { Thermal } \\
\text { Efficiency } \\
\text { in \% }\end{array}$ \\
\hline 1 & 1490 & 1 & 0.42 & 0.214 & 1.96 & 5.53 \\
\hline 2 & 1470 & 2 & 0.51 & 0.422 & 1.2 & 8.98 \\
\hline 3 & 1460 & 3 & 0.62 & 0.629 & 0.98 & 11.01 \\
\hline 4 & 1450 & 4 & 0.88 & 0.833 & 1.05 & 10.28 \\
\hline 5 & 1430 & 5 & 0.98 & 1.027 & 0.95 & 11.38 \\
\hline
\end{tabular}

\subsection{Table for Emulsion W30 Performance} Characteristics

\begin{tabular}{|c|c|c|c|c|c|c|}
\hline $\begin{array}{c}\text { SR } \\
\text { NO. }\end{array}$ & RPM & $\begin{array}{c}\text { Load } \\
\text { in KG }\end{array}$ & $\begin{array}{c}\mathrm{M}_{\mathrm{f}} \mathrm{IN} \\
\mathrm{KG} / \mathrm{HR}\end{array}$ & $\begin{array}{c}\text { Brake } \\
\text { Power in } \\
\mathrm{KW}\end{array}$ & $\begin{array}{c}\text { Brake Specific } \\
\text { Fuel } \\
\text { Consumption in } \\
\text { KG/(KWHR) }\end{array}$ & $\begin{array}{c}\text { Brake } \\
\text { Thermal } \\
\text { Efficiency } \\
\text { in \% }\end{array}$ \\
\hline 1 & 1490 & 1 & 0.63 & 0.214 & 2.94 & 4.25 \\
\hline 2 & 1470 & 2 & 0.756 & 0.422 & 1.79 & 6.9 \\
\hline 3 & 1460 & 3 & 0.882 & 0.629 & 1.40 & 8.94 \\
\hline 4 & 1450 & 4 & 1.134 & 0.833 & 1.36 & 9.2 \\
\hline 5 & 1430 & 5 & 1.386 & 1.027 & 1.349 & 9.29 \\
\hline
\end{tabular}

\section{Graphs}
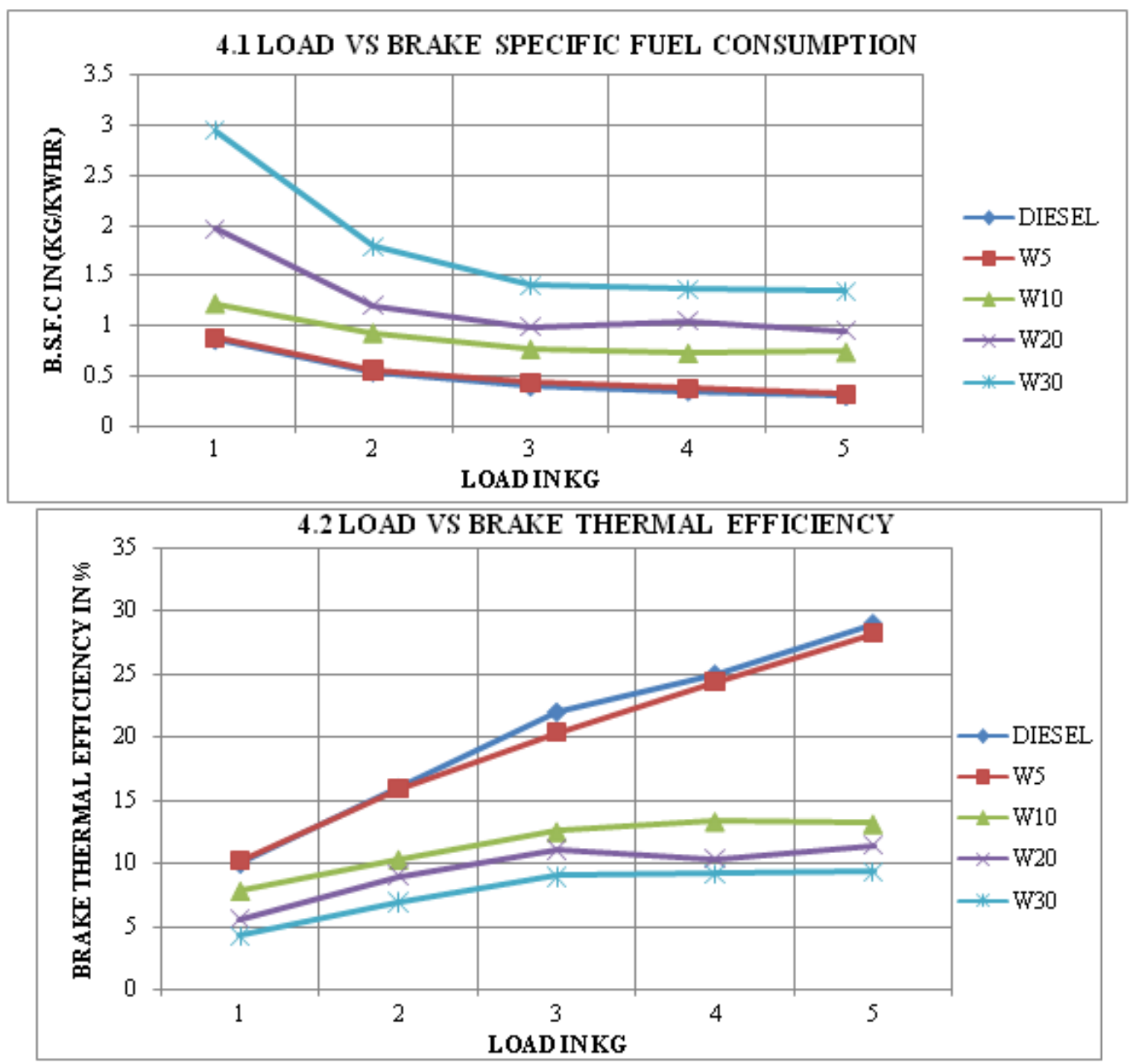

Volume 5 Issue 4, April 2016

www.ijsr.net 


\section{International Journal of Science and Research (IJSR) \\ ISSN (Online): 2319-7064}

Index Copernicus Value (2013): 6.14 | Impact Factor (2015): 6.391

\section{Result and Discussions}

From the trend shown in the graphs it is clear that as the load increases the brake specific fuel consumption decreases when running the diesel engine on pure diesel oil as fuel. But when we use W5 as fuel then also we get the same trend of brake specific fuel consumption with additional advantage of low harmful exhaust emissions. Moreover when we increase the water content in fuel for example W30 there is considerable increase in brake specific fuel consumption at all loads which is a disadvantageous situation. Also from the trend shown in the graph brake thermal efficiency is almost same for pure diesel and W5 but there is considerable reduction in brake thermal efficiency when we use W30, W20 or W10 at all the loads.

\section{Conclusion and Future Scope}

We arrive at a conclusion about the effectiveness of W5 emulsion as alternative fuel because it gives high brake thermal efficiency along with low brake specific fuel consumption at all loads on the engine. Moreover it also gives less harmful emissions from the engine and less thermal energy loss from jacket water cooling or exhaust of the engine.

\section{References}

[1] AnnaLif et al "Water-in-diesel emulsions and relatedsystems"

[2] Christopher J. Chadwell et al "Effect of Diesel and Water Co-injection with Real-Time Control on Diesel Engine Performance andEmissions"

[3] Prof. Snehal M. Chaudhari et al "Effect of Metal Based Additives on a CI Engine Fuelled with Diesel andWater"

[4] Pradeep Kumar et al“Effect of Emulsified Fuel on Performance and Emission Characteristics in DI DieselEngine"

[5] OmarBadran et al"Impact of Emulsified Water/Diesel Mixture on Engine Performance and Environment"

[6] Miqdam Tariq Chaichan et al "Enhancement of DI Compression Ignition Engine Performance and Emission Using Diesel - Water Emulsion asFuel"

[7] Hrishikesh Sane et al "Emission Reduction of IC Engines by using Water-in-Diesel Emulsion and CatalyticConverter"

[8] Pradeep S. Kumar et al "Emission Control by using Water Emulsified Diesel in Single Cylinder DieselEngine"

[9] H.GKatariya et al textbook on Internal combustion engines published by Books India Publication.

[10] JamilGhojel, Damon Honnery, Khaled Al-Khaleefi. 2006. Performance, emission and heat release characteristics of direct injection diesel engine operating on diesel oil emulsion. Applied Thermal Engineering. 26: 2132-2141.

[11] J.W. Park, K.Y. Huh, K.H. Park. 2000. Experimental study on the combustion characteristics of emulsified diesel in a rapid compression and expansion machine. Proc. Instn. Mech. Engrs. 214: 579-585.
[12] M. Abu-Zaid. 2004. Performance of single cylinder, direct injection diesel engine using water fuel emulsions. Energy Conversion and Management. 45: 697-705.

[13] O. Armas, R. Ballenseros, F.J. Martos, J.R. Agudelo. 2005. Characterization of light duty diesel engine pollutant emissions using water-emulsified fuel. Fuel. 84: 1011-1018.

[14] J.W. Park, K.Y. Huh, J.H. Lee. 2001. Reduction of NOx, smoke and brake specific fuel consumption with optimal injection timing and emulsion ratio of wateremulsified diesel. Proc. Instn. Mech. Engrs. 215: 83-93.

[15] Bertrand D. Hsu. Combustion of water-in-diesel emulsion in an experiment medium speed diesel engine.SAE. 860300. pp. 2285-2295.

[16] Kweonha Park, InseokKwak, Seungmook Oh. 2004. The effect of water emulsified fuel on a motorway-bus diesel engine. KSME International Journal. 18: 20492057. 